\title{
ATRX Negative
}

National Cancer Institute

\section{Source}

National Cancer Institute. ATRX Negative. NCI Thesaurus. Code C156047.

An indication that AT RX expression has not been detected in a sample. 